\title{
Insulin-Like Growth Factor I Is the Key Growth Factor in Serum That Protects Neuroblastoma Cells From Hyperosmotic-Induced Apoptosis
}

\author{
CYNTHIA M. VAN GOLEN AND EVA L. FELDMAN* \\ Department of Neurology and Neuroscience Program, University of Michigan, \\ Ann Arbor, Michigan
}

\begin{abstract}
Neuroblastoma is a childhood tumor of the peripheral nervous system that remains largely uncurable by conventional methods. Mannitol induces apoptosis in neuroblastoma cell types and insulin-like growth factor I (IGF-I) protects these cells from hyperosmotic-induced apoptosis by affecting apoptosis-regulatory proteins. In the current study, we investigate factors that enable $\mathrm{SH}-\mathrm{SY} 5 \mathrm{Y}$ neuroblastoma cells to survive in the presence of an apoptotic stimulus. When SH-SY5Y cells are exposed to high mannitol concentrations, more than $60 \%$ of the cells are apoptotic within $48 \mathrm{~h}$. Normal CS prevents hyperosmotic-induced apoptosis in a dose-dependent manner, with $0.6 \%$ CS protecting $50 \%$ of the cells, and $3 \%$ CS rescuing more than $70 \%$ of the cells from apoptosis. Serum also delays the commitment point for SH-SY5Y cells from $9 \mathrm{~h}$ to $35 \mathrm{~h}$. A survey of several growth factors, including epidermal growth factor (EGF), platelet-derived growth factor (PDGF), nerve growth factor (NGF), fibroblast growth factor (FGF), and IGF-I reveals that IGF-I is a component of serum necessary for protection of neuroblastoma cells from death. Mitochondrial membrane depolarization occurs in greater than $40 \%$ of the cells after mannitol exposure and caspase- 3 activation is increased in high mannitol conditions after 9 h. IGF-I blocks both the mitochondrial membrane depolarization and caspase- 3 activation normally induced by hyperosmotic treatment in neuroblastoma cells. Our results suggest that (1) IGF-I is a key factor in serum necessary for protection from death and (2) IGF-I acts upstream from the mitochondria and the caspases to prevent apoptosis in human neuroblastoma. J. Cell. Physiol. 182:24-32, 2000. @ 2000 Wiley-Liss, Inc.
\end{abstract}

Neuroblastoma is a tumor that arises from primordial neural crest cells which form the sympathetic nervous system, including the adrenal medulla and the spinal sympathetic ganglia (Castleberry, 1997; Cianfarani and Rossi, 1997). Although the pathogenesis of neuroblastoma is unknown, one hypothesis is that improper differentiation of the neural crest cells gives rise to malignant tumors (Castleberry, 1997). Neuroblastic tumors account for $8 \%-10 \%$ of all childhood cancers, with most cases detected in children younger than 10 years of age (Castleberry, 1997). Neuroblastomas are enigmatic in that some tumors spontaneously regress, while others, particularly in children over the age of 1 , progress even under a rigorous treatment regimen (Brodeur et al., 1997; Cianfarani and Rossi, 1997; Nakagawara et al., 1997).

Several cloned tumor lines from individual patients are studied to understand neuroblastoma biology better (Ciccarone et al., 1989). One such line, SK-N-SH, was subcloned into two different lines, SH-SY5Y and SHEP (Biedler et al., 1988). These two subcloned lines have distinct features: SH-SY5Y cells are neuron-like, will grow in mitogen-free media, exhibit anchorage- dependent growth (Biedler et al., 1988), and express both insulin-like growth factor II (IGF-II) and functional type I IGF receptor (IGF-IR) (Leventhal et al., 1995; Martin et al., 1993a, 1993b); SHEP cells require serum for growth, are anchorage dependent, do not express IGF-II, and express very little IGF-IR (Biedler et al., 1988; Leventhal et al., 1995).

Recently, apoptosis has emerged as an important aspect of normal development (Gelbard et al., 1997; Jacobson et al., 1997) and tumor biology (reviewed in Hickman, 1992; Kerr et al., 1994; Martin and Green, 1995; Schulte-Hermann et al., 1994). Apoptosis is a type of cell death distinct from necrosis and is charac-

Contract grant sponsor: NCI Cancer Biology Training Program Grant; Contract grant number: 3 T32 CA09676; Contract grant sponsor: NIH; Contract grant number: NS36778, NS38849; Contract grant sponsor: American Diabetes Association; Contract grant sponsor: Juvenile Diabetes Foundation.

*Correspondence to: Eva L. Feldman, M.D., Ph.D., University of Michigan Department of Neurology, 200 Zina Pitcher Place, 4414 Kresge III, Ann Arbor, MI 48109. E-mail: efeldman@umich.edu

Received 29 March 1999; Accepted 20 July 1999 
terized by morphological features such as membrane blebbing, chromatin condensation, and DNA fragmentation (Pittman et al., 1993). Apoptosis in tumor cells occurs spontaneously near areas of necrosis, as well as in response to radiation and chemotherapeutic drug exposure, the classic cancer therapy regimen (Kerr et al., 1994). Interference with the apoptotic pathway may give tumor cells, including neuroblastoma, a survival advantage as well as conferring on them resistance to drug therapy (Gelbard et al., 1997; Hickman 1992).

Growth factors can block apoptosis, and in turn, serve as survival factors during normal nervous system development. Nerve growth factor (NGF) is essential for the survival of sympathetic neurons (Deshmukh and Johnson, 1997; Cameron et al., 1991; Vogelbaum et al., 1998), and epidermal growth factor (EGF) and platelet-derived growth factor (PDGF) can regulate central nervous system and neural crest cell development, respectively (Kornblum et al., 1998; Soriano 1997). Growth factors or growth factor receptors also protect neuroblastoma cells from cell death, contributing to abnormal growth and resistance to treatment. NGF blocks apoptosis in primary neuroblastoma (Nakagawara and Brodeur, 1997). NGF can also protect SK-N-SH neuroblastoma cells from chemotherapy induced apoptosis (Falcione et al., 1993) while PDGF prevents murine neuroblastoma cells from undergoing apoptosis upon serum withdrawal (Funa and Ahgren, 1997), and FGF delays apoptosis in human glial cell tumors (Murai et al., 1996).

We are interested in the role of IGF-I, IGF-II, and IGF-IR in neuroblastoma tumorigenesis. Similar to other growth factors, the IGFs protect neuronal cells from apoptosis and contribute to tumor growth and resistance to treatment (O'Connor, 1998). SH-SY5Y and SHEP human neuroblastoma cells undergo apoptosis when grown in hyperosmotic media and IGF-I is neuroprotective (Cheng and Feldman, 1998; Matthews and Feldman, 1996; Matthews et al., 1997; Singleton et al., 1996b). New protein synthesis is not required for either of these processes (Matthews et al., 1997). Large DNA fragments are formed within $1 \mathrm{~h}$ of hyperosmotic exposure, the cells are committed to die at $12 \mathrm{~h}$, and small DNA fragments are detected at $24 \mathrm{~h}$ (Matthews and Feldman 1996; Matthews et al., 1997). Hyperosmotic stress also decreases the protein expression of

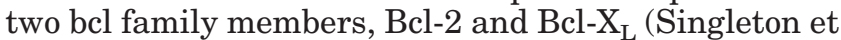
al., 1996a). In these same studies, IGF-I prevents apoptosis, maintains Bcl-2 and Bcl-X $\mathrm{X}_{\mathrm{L}}$ levels, and prevents caspase-3 and caspase-7 activation (Matthews et al., 1997; Singleton et al., 1996a).

In the current study, the ability of growth factors other than IGF-I to rescue SH-SY5Y human neuroblastoma cells from hyperosmotic-induced apoptosis was investigated. The protective effects of several growth factors were compared to IGF-IR-mediated protection. Under conditions of hyperosmotic-mediated death, IGF-I affords more neuroprotection than the neurotrophins, FGF or EGF. This neuroprotection is due, in part, to the ability of IGF-I to regulate changes in mitochondrial membrane potentials and to block caspase activation. These data further support the pivotal role of IGFs and IGF-IR in neuroblastoma tumorigenesis.

\section{METHODS \\ Materials}

Tissue culture plastic was purchased from Corning (Corning, NY). Dulbecco's Modified Eagle's Medium (DMEM), Hank's Balanced Salt Solution (HBSS), and calf serum (CS) were purchased from Gibco BRL (Gaithersburg, MD). IGF-I was provided by Cephalon, Inc. (West Chester, PA) and stored in $10 \mathrm{mM}$ acetic acid at $-80^{\circ} \mathrm{C}$. All other chemicals were purchased from Sigma Chemical Company (St. Louis, MO).

\section{Cell culture}

SH-SY5Y human neuroblastoma cells were grown in DMEM plus $10 \% \mathrm{CS}$ at $37^{\circ} \mathrm{C}$ in a humidified atmosphere with $10 \% \mathrm{CO}_{2}$. Cells were routinely subcultured after removing the cells from the plates with trypsinEDTA (Gibco BRL).

\section{Flow cytometry}

Cells were plated at $1 \times 10^{5}$ cells $/ \mathrm{cm}^{2}$ density in 6 -well plates. After cells reached near confluence (about $2 \mathrm{~d}$ ), cells were placed in serum-free media for $4 \mathrm{~h}$ before exposure to experimental conditions. At appropriate time periods, cells were lifted from the plates with trypsin-EDTA. The trypsinized cells and culture media containing any detached cells were combined, washed in $\mathrm{HBSS}$ without $\mathrm{Ca}^{2+}$ or $\mathrm{Mg}^{2+}$, fixed using ice-cold $70 \%$ ethanol, and stored at $4^{\circ} \mathrm{C}$. Fixed cells were rinsed in HBSS without phenol red and stained 2-12 h with $18 \mu \mathrm{g} / \mathrm{ml}$ propidium iodide containing 40 $\mu \mathrm{g} / \mathrm{ml}$ RNase A at $4^{\circ} \mathrm{C}$. Propidium iodide intercalates into the DNA, allowing total DNA content to be measured for each cell. The cells can then be placed into each phase of the cell cycle based on DNA content. Apoptotic cells characteristically have DNA that is fragmented into 180-200 base pair fragments. These fragments are then represented as a sub- $G_{O}$ peak on the cell cycle histogram. Data were measured and collected on an Epics Elite flow cytometry system (Coulter Cytometry, Hialeah, FL). The percent apoptotic cells in all flow cytometry experiments represents the \% sub- $\mathrm{G}_{\mathrm{O}}$ DNA content.

\section{Bisbenzimide staining}

Bisbenzimide is a nuclear stain that gives a clear representation of nuclear morphology. Cells were grown in DMEM supplemented with $10 \%$ CS on glass coverslips. After treatment, cells were fixed in $4 \%$ paraformaldehyde for $15 \mathrm{~min}$, rinsed in phosphate-buffered saline (PBS0, and stained with $1 \mu \mathrm{g} / \mathrm{ml}$ bisbenzimide in PBS for $30 \mathrm{~min}$. After staining, coverslips were rinsed in PBS and mounted onto slides. Cells were viewed under ultraviolet illumination on a Leitz Orthoplan microscope (Leica Microsystems Inc., Deerfield, IL).

\section{Western blotting}

Western blot analyses were performed as previously described (Leventhal et al., 1995). Equal amounts of protein $(70 \mu \mathrm{g})$ were loaded in each experiment. To verify protein transfer, nitrocellulose membranes were stained with Ponceau S. Mouse monoclonal antibodies to Bcl-2 and horseradish peroxidase conjugated secondary antibodies were purchased from Santa Cruz Biotechnology, Santa Cruz, California. Anticaspase-3 
polyclonal antibody was purchased from Pharmingen (San Diego, CA). Nitrocellulose membranes were incubated with primary antibody (1:1000 dilution) for $2 \mathrm{~h}$, incubated with secondary antibody (1:2000) for $1 \mathrm{~h}$, developed with enhanced chemiluminescent Western blotting detection system (ECL) (Amersham, Arlington Heights, IL), and exposed to film (Hyperfilm-ECL, Amersham). Blots shown are one of at least three independent experiments performed.

\section{Rh123 fluorescence}

Rhodamine 123 (Rh123) is a vital dye that is preferentially taken up by the mitochondria. Loss of RH123 fluorescence indicates a loss of mitochondrial membrane potential. Cells were treated for flow cytometry as described above. After $18 \mathrm{~h}$ of treatment, cells were exposed to $5 \mu \mathrm{g} / \mathrm{ml} \mathrm{Rh} 123$ in HBSS for $30 \mathrm{~min}$ at $37^{\circ} \mathrm{C}$. Cells were then lifted from the plate with trypsinEDTA, stained with propidium iodide as described above, and immediately read on the flow cytometer. Results shown are the percent of viable (propidium iodide excluding) cells that have a Rh123 fluorescence lower than control levels.

\section{Statistical analyses}

All data presented graphically are means of at least three separate experiments shown \pm SEM. Data were analyzed using a Welch's nonparametric unpaired $t$ test unless otherwise indicated.

\section{Serum rescues SH-SY5Y cells from apoptosis}

We have previously shown that SH-SY5Y cells survive under serum-free conditions and that the percent of cells undergoing apoptosis is similar in the presence or absence of serum (Singleton et al., 1996b). However, on addition of mannitol to serum-free media, the cells detach from the plate and display the characteristics of apoptosis (Matthews and Feldman, 1996). Mannitol was chosen as a pro-apoptotic compound in our experiments because it can enhance the therapeutic effectiveness of chemotherapy drugs (Neuwelt and Rapoport, 1984; Neuwelt et al., 1986). Although the concentrations of mannitol needed to produce apoptosis in vitro are well beyond physiological levels, in vivo hyperosmolar changes in the tumor microenvironment could aid in inducing apoptosis, particularly if those hyperosmolar changes cause mitochondrial damage and/or changes in Bcl protein expression.

As a starting point for our investigation of which growth factors other than IGF-I serve as survival factors for SH-SY5Y cells, we examined the ability of normal CS to rescue these cells from apoptosis. CS contains a wide variety of growth factors and cytokines that enhance the growth of cells in culture. On exposure to $300 \mathrm{mM}$ mannitol, 37\% of SH-SY5Y cells become apoptotic by $24 \mathrm{~h}$ (Fig. 1A). After $48 \mathrm{~h}$ of hyperosmotic exposure, $64 \%$ of the cells undergo apoptosis, and the number of dying cells increases to over $70 \%$ at 72 and 96 h (Fig. 1A). Morphological changes characteristic of apoptosis, such as membrane blebbing and chromatin condensation, are present using light or transmission electron microscopy in these cells after $48 \mathrm{~h}$ of exposure to $300 \mathrm{mM}$ mannitol (data not shown). After establishing that mannitol induces apoptotic death in SH-SY5Y cells, CS was added into the media to see if apoptosis would be prevented. When $10 \% \mathrm{CS}$ is added into solution, $80 \%$ of those cells are protected from hyperosmotic-induced death, with only $9 \%$ of the cells undergoing apoptosis after 2 d (Fig. 1A). This protective effect is seen even after $4 \mathrm{~d}$, when more than $75 \%$ of the cells are apoptotic in $300 \mathrm{mM}$ mannitol, whereas apoptotic cells in $300 \mathrm{mM}$ mannitol plus CS are near control levels. When $10 \%$ CS is present, no morphologically apoptotic cells are seen, although cells do appear shrunken compared to cells in DMEM alone or cells in DMEM plus 10\% CS. Cells exposed to hyperosmotic media with CS added appeared no different ultrastructurally from those in isotonic media as examined by electron microscopy (data not shown).

To determine an effective dose of CS for protection of SH-SY5Y cells against apoptosis, increasing concentrations of CS were added to cells in either isotonic or hyperosmotic media (Fig. 1B). Once again, cells in isotonic media are viable throughout the experiment. However, in hyperosmotic media, the percentage of cells is significantly increased; $34 \%$ of cells are apoptotic by $24 \mathrm{~h}$ in $300 \mathrm{mM}$ mannitol with no CS present versus $2 \%$ in DMEM. Increasing concentrations of CS results in a dose-dependent rescue of the cells. After $24 \mathrm{~h}$, more than $50 \%$ of the cells are protected from apoptosis with $1 \%$ serum, while approximately $80 \%$ of cells are rescued by $3 \%$ serum. There is little difference in rescue at concentrations above 3\%; however, the remainder of experiments in this study were performed using $10 \%$ serum to ensure maximum protective effects over time courses longer than $48 \mathrm{~h}$.

To determine the time point at which hyperosmoticexposed SH-SY5Y cells are committed to die, serum deprived cells were exposed to $300 \mathrm{mM}$ mannitol. Ten percent CS was added at time periods between 0 and $48 \mathrm{~h}$. After $48 \mathrm{~h}$ of exposure, cells were prepared for flow cytometry and stained with propidium iodide (Fig. 1C). We did not observe one distinct point after which rescue with serum was unachievable. Rather, the number of apoptotic cells increases in an almost linear fashion as the time increases between hyperosmotic exposure and serum addition. When serum is present at the time of exposure to mannitol, $8 \%$ of the cells undergo apoptosis (Fig. 1C). The percentage of apoptotic cells increases steadily over the course of the experiment. The point at which 50\% of the cells are apoptotic is at approximately $35 \mathrm{~h}$. To verify that this delay in commitment point was due to the addition of CS, a study was performed in which cells were exposed to 300 $\mathrm{mM}$ mannitol at time 0 , and at the indicated time points, mannitol was removed and replaced by DMEM (isotonic media). When hyperosmotic media is replaced by isotonic media, the point at which $50 \%$ of cells die is between $9 \mathrm{~h}$ and $12 \mathrm{~h}$ (Fig. 1d). Therefore, serum has the ability to prolong the commitment point after which time the apoptotic program cannot be reversed.

\section{IGF-I is a major component of serum that protects cells from apoptosis}

Serum contains many different growth factors and cytokines that play a protective role in other cell types. To investigate which of these factors are antiapoptotic in neuroblastoma cells, different growth factors were surveyed for their ability to block DNA fragmentation 

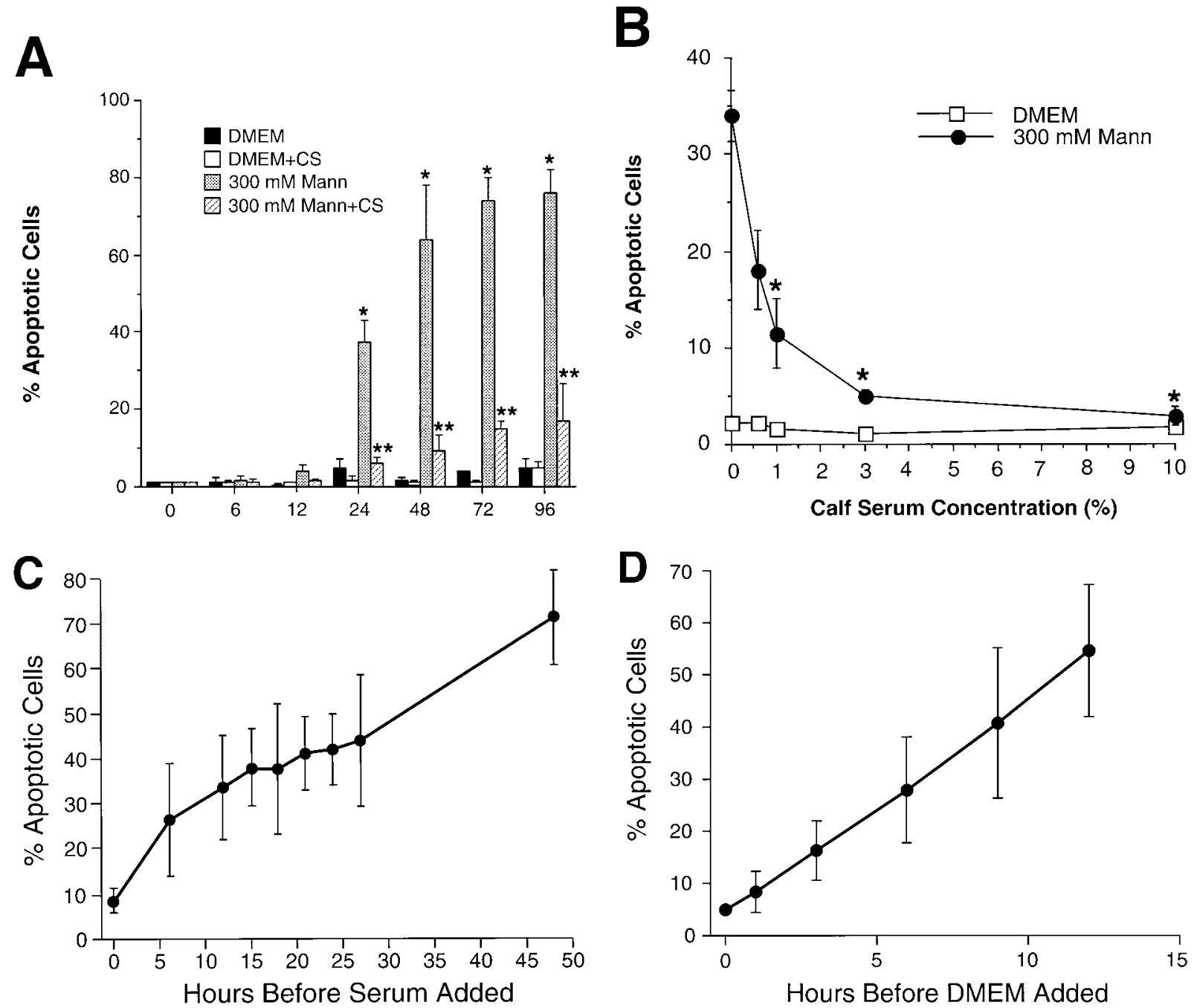

Fig. 1. A: Serum rescues SH-SY5Y cells from hyperosmotic-induced apoptosis. Cells were serum starved overnight, then exposed to either Dulbecco's Modified Eagle's Medium (DMEM) $\pm 10 \%$ calf serum (CS) or $300 \mathrm{mM}$ mannitol $\pm 10 \% \mathrm{CS}$. At the times indicated, cells were prepared for flow cytometry and stained with propidium iodide. By $48 \mathrm{~h}$, mannitol significantly increases the percentage of apoptotic cells as determined by analysis of variance (ANOVA), and 10\% CS returns the number of apoptotic cells to control levels. The values listed are mean \pm SEM for three separate experiments. An asterisk $(*)$ means the value is statistically significant $(P<0.01)$ compared with DMEM at time 0 . A double asterisk (**) means the value is statistically significant $(P<0.01)$ compared to $300 \mathrm{mM}$ mannitol for that time point. B: Serum rescues neuroblastoma cells in a dose-dependent manner. Serum starved cells were exposed to DMEM or $300 \mathrm{mM}$ mannitol and $0 \%, 0.6 \%, 15,3 \%$, or $10 \% \mathrm{CS}$. After $24 \mathrm{~h}$, cells were prepared for flow cytometry and stained with propidium iodide. Ad-

as measured by flow cytometry. Growth factors included in this survey were IGF-I, EGF, acidic fibroblast growth factor $(\alpha \mathrm{FGF})$, basic fibroblast growth factor $(\beta F G F), N G F$, and PDGF, in addition to serum itself. The only growth factor tested that produced an effect similar to serum is IGF-I; IGF-I and $1 \%$ CS both reduced the amount of cells undergoing apoptosis from $67 \%$ to $28 \%$ and $25 \%(P<0.005)$, respectively, after $48 \mathrm{~h}$ of exposure (Fig. 2). Ten percent CS significantly $(P=0.0005)$ reduces the number of apoptotic cells to

dition of $1 \%$ CS or greater decreases the number of apoptotic cells to levels statistically similar to controls. The values shown are mean \pm SEM for three separate experiments. An asterisk $(*)$ means the value is statistically significant $(P<0.01)$ compared with $300 \mathrm{mM}$ mannitol. C: Determination of serum rescue point. Serum-deprived cells were exposed to $300 \mathrm{mM}$ mannitol at time 0 . At the indicated times, the solution was removed from the cells and replaced by $300 \mathrm{mM}$ mannitol plus $10 \% \mathrm{CS}$. After $48 \mathrm{~h}$ of exposure, cells were prepared for flow cytometry and stained with propidium iodide. Values given are mean \pm SEM for three separate experiments. D: Determination of isotonic rescue point. SH-SY5Y cells were serum deprived overnight, then exposed to $300 \mathrm{mM}$ mannitol. At the indicated times, the solution was aspirated from the cells, and fresh DMEM was added to the wells. $48 \mathrm{~h}$ postexposure, the cells were collected, prepared for flow cytometry, and stained with propidium iodide. Values given are the mean \pm SEM for three separate experiments.

less than $10 \%$. The concentration of IGF-I in this lot of CS as measured by radioimmunoassay was $3.6 \mathrm{nM}$ in $10 \% \mathrm{CS}$, which is well below the $10 \mathrm{nM}$ IGF-I used in all of the experiments in this study. Therefore, the greater protective effect elicited by CS is not due solely to IGF-I levels. The only other growth factor to produce an effect was EGF, which reduces the percentage of apoptotic cells from $67 \%$ to $44 \%$. The difference between EGF and any other treatment was not statistically significant, however, indicating that EGF rescues 


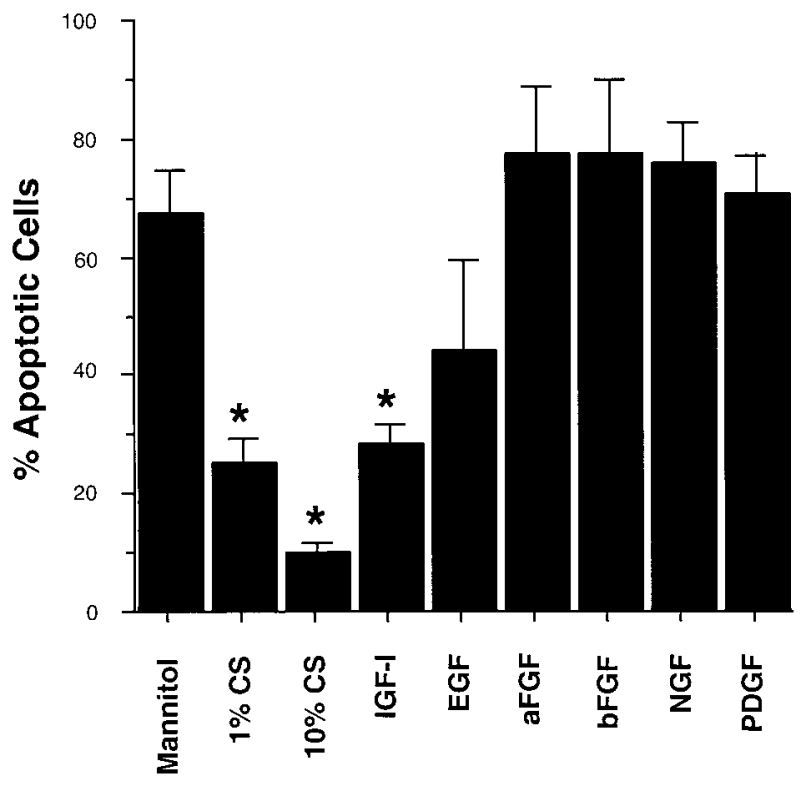

Fig. 2. Comparison of the rescue ability of a variety of growth factors. SH-SY5Y cells were placed in serum free media overnight, then exposed to $300 \mathrm{mM}$ mannitol $\pm 1 \%$ calf serum (CS), $10 \% \mathrm{CS}, 10$ $\mathrm{nM}$ insulin-like growth factor I (IGF-I), $10 \mathrm{ng} / \mathrm{ml}$ epidermal growth factor (EGF), $10 \mathrm{ng} / \mathrm{ml}$ acidic fibroblast growth factor (aFGF), 10 $\mathrm{ng} / \mathrm{ml}$ basic fibroblast growth factor (bFGF), $10 \mathrm{ng} / \mathrm{ml}$ nerve growth factor (NGF), or $10 \mathrm{ng} / \mathrm{ml}$ platelet-derived growth factor (PDGF). After $48 \mathrm{~h}$, cells were prepared for flow cytometry and stained with propidium iodide. The difference between IGF-I or 1\% CS and $300 \mathrm{mM}$ mannitol was statistically significant $(P<0.005)$. The difference between $10 \% \mathrm{CS}$ and $300 \mathrm{mM}$ mannitol was statistically extremely significant $(P=0.0005)$. The values shown are the mean \pm SEM for three separate experiments. An asterisk (*) means the value is statistically significant $(P<0.01)$ compared with $300 \mathrm{mM}$ mannitol.

SH-SY5Y cells from hyperosmotic-induced apoptosis at an intermediate level. None of the other growth factors tested protect $\mathrm{SH}-\mathrm{SY} 5 Y$ cells from apoptosis induced by hyperosmolar stress. SH-SY5Y cells produce endogenous IGF-II, which can also activate the IGF-IR (Martin and Feldman 1993; Martin et al., 1993). However, studies using $\alpha$-IR3, a blocking antibody for the IGFIR, indicate that endogenous IGF-II production does not play a role in protecting these cells from hyperosmotic-induced apoptosis. In hyperosmotic conditions, the percentage of apoptotic cells after $24 \mathrm{~h}$ was $40.3 \%$; when $\alpha$-IR3 was present, the percentage of apoptotic cells was $36 \%$ (data not shown). Because endogenous IGF-II had no effect on protection of these cells, exogenous IGF-II was not included in the growth factor survey.

To support the importance of IGF-I as a serum component necessary for neuroblastoma survival, morphological characteristics of SH-SY5Y cells were examined under different conditions using bisbenzimide to stain the nuclei of the cells. Cells in isotonic media appear normal with or without serum or IGF-I present (Fig. 3 A, B, C). On addition of $300 \mathrm{mM}$ mannitol for $24 \mathrm{~h}$, fragmented nuclei are seen, with a dramatic decrease in cell density (Fig. 3D). When serum or IGF-I is added to the media, the number of fragmented nuclei dramatically decreases, and the cell viability increases greatly (Fig. 3E, F). Based on the results above, we conclude that IGF-I is the growth factor most effective in preventing hyperosmotic-induced apoptosis. Therefore, the remainder of our experiments focused on understanding the mechanism whereby IGF-I prevents mannitol-mediated apoptosis in SH-SY5Y cells.

IGF-I prevents mitochondrial membrane depolarization induced by hyperosmotic stress

Changes in mitochondrial function play a pivotal role in several aspects of apoptosis. We investigated the effects of hyperosmotic stress and IGF-I addition on mitochondrial membrane potential as a measure of mitochondrial function. Mitochondria are depolarized when SH-SY5Y cells are exposed to increasing concentrations of mannitol. As the environment becomes more hyperosmolar, more cells undergo apoptosis (Fig. 4A). Significant $(P<0.01)$ increases in apoptosis are not seen until the mannitol level exceeds $200 \mathrm{mM}$. A similar result is seen when Western blot analysis is performed for activated caspase-3 (data not shown). Mitochondrial membrane depolarization is detected at an earlier time point than DNA fragmentation. At $18 \mathrm{~h}$ posttreatment, the mitochondrial membrane is depolarized in approximately $45 \%$ of SH-SY5Y cells exposed to $300 \mathrm{mM}$ mannitol, versus $23 \%$ of cells in DMEM alone (Fig. 4B). Next, $10 \mathrm{nM}$ IGF-I is added to the media, and the mitochondrial membrane potential is studied. In the presence of IGF-I, the number of cells showing mitochondrial membrane depolarization is very similar to control (Fig. 4B).

\section{Caspase-3 is activated by hyperosmotic stress and is prevented by IGF-I in SH-SY5Y cells}

Caspase-3 activation is one of the later events in the apoptotic cascade and is necessary for apoptosis to occur in many systems (Janicke et al., 1998; Woo et al., 1998). Activation of effector caspases is downstream from the regulation point of the Bcl proteins and the events that occur at the mitochondria (Chinnaiyan et al., 1996; Zha et al., 1996). In the current study we examined the time course of caspase- 3 activation in SH-SY5Y cells. Caspase-3 is cleaved from a $32 \mathrm{kDa}$ protein into 17 and $14 \mathrm{kDa}$ products to become active. These activation bands can be detected through Western immunoblotting in all conditions, but increase in intensity after $9 \mathrm{~h}$ of hyperosmotic stress, with cleavage products detected through $24 \mathrm{~h}$ (Fig. 5A). A similar pattern is observed for caspase-7, another effector caspase thought to act parallel to caspase-3 (data not shown). Next, caspase activation was examined in the absence or presence of IGF-I after 3 or $6 \mathrm{~h}$ of exposure to $300 \mathrm{mM}$ mannitol. No cleavage products are detected in control conditions. Activation bands are again seen when cells are exposed to hyperosmotic media. As predicted, IGF-I addition blocks caspase-3 cleavage (Fig. 5B). A similar pattern was again observed for caspase-7 (data not shown). Together these data suggest that hyperosmotic-induced apoptosis is a caspasedependent form of apoptosis. IGF-I acts to prevent caspase activation, either through direct or indirect interference with the caspase cascade.

\section{DISCUSSION}

Because neuroblastoma is resistant to many types of therapy, we are interested in determining the factors 

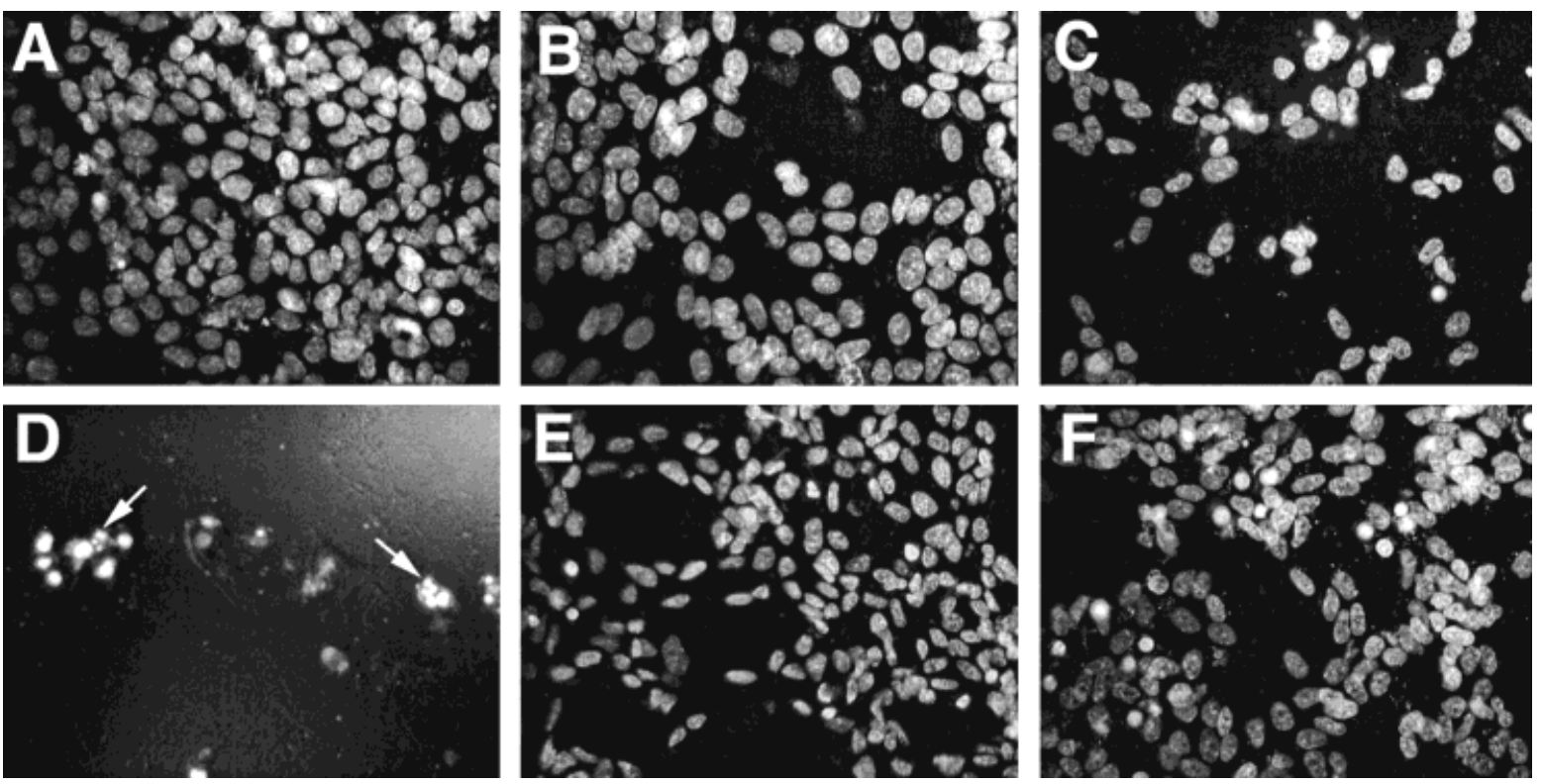

Fig. 3. A-F: Morphological comparison of serum and insulin-like growth factor I (IGF-I) rescue. Serum-deprived cells were exposed to (A) Dulbecco's Modified Eagle's Medium (DMEM); (B) DMEM plus 10\% calf serum (CS); (C) DMEM + 10 nM IGF-I; (D) 300 mM mannitol; (E)
$300 \mathrm{mM}$ mannitol plus $10 \% \mathrm{CS}$; or $(\mathbf{F}) 300 \mathrm{mM}$ mannitol plus $10 \mathrm{nM}$ IGF-I. After $24 \mathrm{~h}$ of exposure, cells were fixed, rinsed, and stained with bisbenzimide. Cells exposed to $300 \mathrm{mM}$ mannitol show fragmented nuclei. Representative fields are shown for each condition. that enhance neuroblastoma cell survival. We have previously reported that IGF-I protects neuroblastoma from apoptosis (Matthews and Feldman, 1996; Matthews et al., 1997; Singleton et al., 1996a,b). In the current study, we examined the potential role of other growth factors in neuroblastoma survival and compared the protective effects of these growth factors to IGF-I.

We began by investigating the ability of CS to rescue neuroblastoma cells from hyperosmotic-induced apoptosis. CS contains a wide variety of factors known to protect cells from death, including IGF-I. We found that CS protects SH-SY5Y cells from hyperosmotic shock in a dose-dependent manner, with as little as $1 \%$ CS exerting a protective effect. CS also delays the point at which cells are committed to die. In our experiments, CS protects neuroblastoma cells from apoptosis better than IGF-I alone. These data led us to examine the ability of growth factors, other than IGF-I, to block hyperosmotic-mediated apoptosis.

In SH-SY5Y neuroblastoma cells, other growth factors had little or no protective effect when compared to IGF-I. These data are interesting in light of several reports of the neuroprotective effects of these growth factors in neuroblastoma. NGF promotes survival and differentiation of early stage and stage $4 \mathrm{~S}$ neuroblastoma tumors (Nakagawara and Brodeur, 1997). NGF also prevents neocarzinostatin-induced apoptosis in SK-N-SH cells, the line from which SH-SY5Y cells were derived (Falcione et al., 1993). PDGF can rescue NB41 neuroblastoma cells from apoptosis induced by serum withdrawal and 6-hyproxydopamine (Funa and Ahgren, 1997). Although FGF only promotes proliferation and enhances phorbol ester-induced differentiation in SH-SY5Y cells (Janet et al., 1995; Lavenius et al., 1994), it does protect U-87MG and U-251UG glioma cells (Murai et al., 1996), as well as NIH3T3 cells (Wieder et al., 1997) from apoptosis.

Clearly, these data suggest that neuroblastoma cell lines display distinct patterns of growth factor mediated survival. While SH-SY5Y cells express Trk A receptors, the primary response of these cells to NGF is differentiation (Lavenius et al., 1995; Poluha et al., 1995), not survival. SH-SY5Y cells undergo terminal differentiation with continuous NGF exposure; once differentiated, these cells are then dependent on NGF for protection from apoptosis (Jensen et al., 1992). These data suggest that NGF is not important for survival in undifferentiated SH-SY5Y cells, and may actually enhance apoptosis in these cells by mediating a more differentiated phenotype. SH-SY5Y cells also express the low affinity NGF receptor p75 (Ehrhard et al., 1993). The p75 receptor has pro-apoptotic activity in response to NGF treatment in SK-N-BE and SKN-MC neuroblastoma cells (Bunone et al., 1997; Kuner and Hertel, 1998). Therefore, NGF could actually enhance apoptosis rather than prevent it in SH-SY5Y cells.

SH-SY5Y cells also express functional PDGF receptors, and PDGF stimulates both proliferation and differentiation in these cells (Janet et al., 1995; Pahlman et al., 1992). A similar effect on SH-SY5Y cells is seen with FGF (Janet et al., 1995; Lavenius et al., 1994). FGF can increase the expression of p75NTR in CHP100 human neuroblastoma cells as well (Taiji et al., 1992), which as mentioned previously, could actually promote apoptosis. EGF can enhance [3H]-thymidine uptake in SK-N-SH, but not SH-SY5Y cells, and only in the presence of fetal bovine serum, suggesting the need for other serum factors to produce a proliferative response (da Motta et al., 1997). Collectively, these reports coupled with the findings from the current study, indicate 

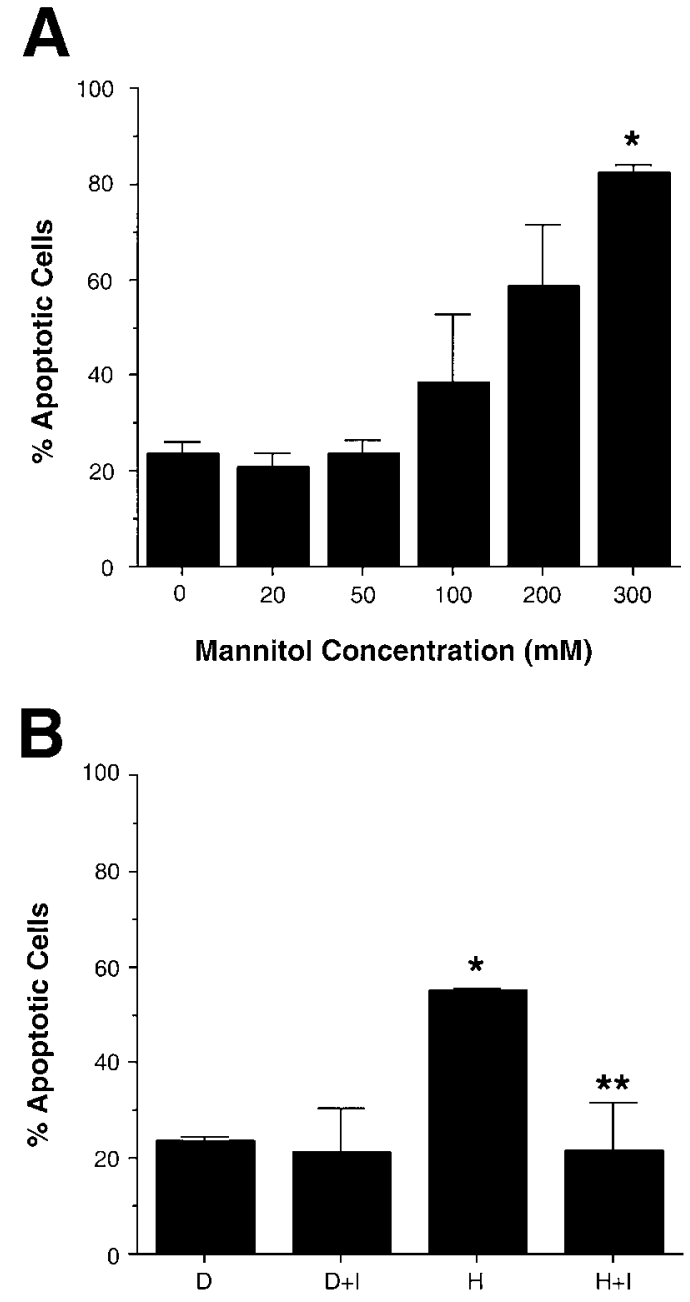

Fig. 4. A: Mannitol causes DNA fragmentation in SH-SY5Y cells. Serum-deprived cells were exposed to $0,20,50,100,200$, or $300 \mathrm{mM}$ mannitol for $48 \mathrm{~h}$, then prepared for flow cytometry. The difference between $300 \mathrm{mM}$ mannitol and $0 \mathrm{mM}$ mannitol is statistically significant $(P=0.0002)$. Results shown are the mean \pm SEM for three separate experiments. An asterisk $(*)$ means the value is statistically significant $(P<0.01)$ compared with $0 \mathrm{mM}$ Mann. B: Insulin-like growth factor I (IGF-I) prevents mitochondrial membrane depolarization in SH-SY5Y cells. Serum-deprived cells were exposed to 0 or 300 $\mathrm{mM}$ mannitol \pm IGF-I for $18 \mathrm{~h}$, then incubated with rhodamine 123 (Rh123) for $30 \mathrm{~min}$ at $37^{\circ} \mathrm{C}$ and prepared for flow cytometry. Results are represented as percentage of propidium iodide excluding cells with Rh123 fluorescence below control levels. The difference between 300 mM mannitol and Dulbecco's Modified Eagle's Medium (DMEM) is statistically significant $(P=0.001)$, and the difference between 300 $\mathrm{mM}$ mannitol plus $10 \mathrm{nM}$ IGF-I is significant $(P<0.01)$. Results are the mean of three experiments plus SEM. An asterisk (*) means the value is statistically significant $(P<0.01)$ compared with DMEM. A double asterisk $(* *)$ means the value is statistically significant $(P<$ 0.01 ) compared to $300 \mathrm{mM}$ mannitol.

that while many growth factors play a role in growth and differentiation of SH-SY5Y cells, IGF-I provides the most potent protection against apoptosis.

Apoptosis is a complex phenomenon regulated by many different proteins, any one of which could be affected by the presence of growth factors. Two major families of apoptosis regulatory proteins exist: the Bcl-2 family and the caspase family. Bcl proteins ap-

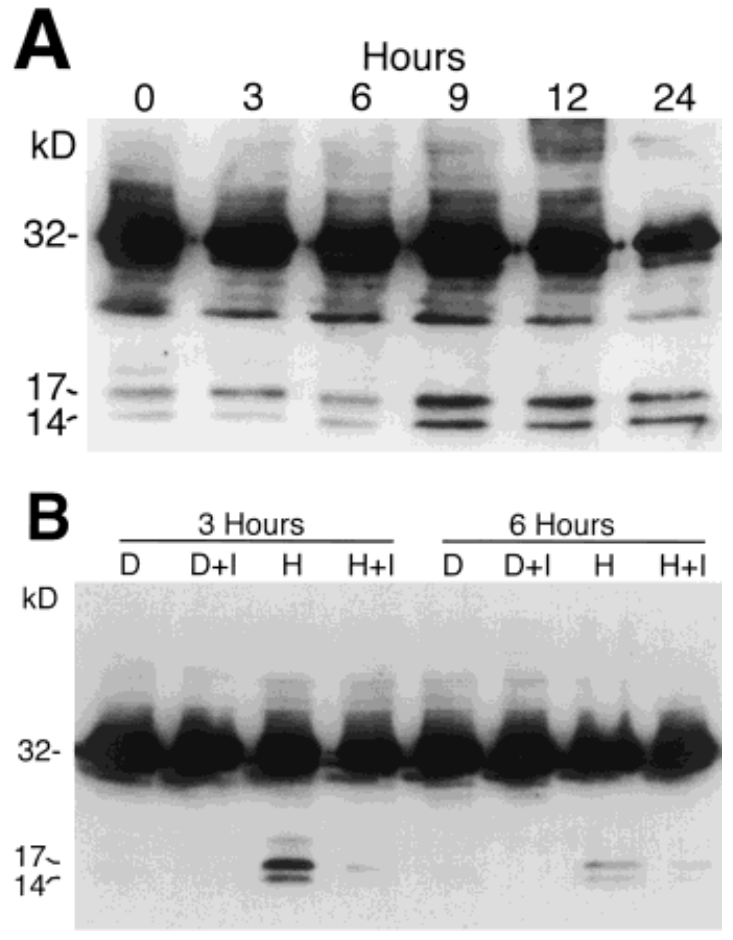

Fig. 5. A: The effect of mannitol exposure on caspase-3 activation in SH-SY5Y cells. Serum-deprived cells were exposed to $300 \mathrm{mM}$ mannitol for the times indicated. Whole-cell lysates were collected, run on a sodium dodecyl sulfate-polyacrylamide gel electrophoresis (SDSPAGE) gel, and Western immunoblotted using a polyclonal anticaspase-3 antibody. Blot shown is one of three performed. B: Insulinlike growth factor I (IGF-I) prevents caspase-3 activation in SH-SY5Y cells after hyperosmotic exposure. Cells were exposed to Dulbecco's Modified Eagle's Medium (DMEM) \pm 10 nM IGF-I or 300 mM mannitol $\pm 10 \mathrm{nM}$ IGF-I for $6 \mathrm{~h}$. Whole-cell lysates were collected, run on an SDS-PAGE gel, and Western immunoblotted using a polyclonal anticaspase-3 antibody. Blot shown is one of three performed.

pear to act upstream from the caspases (Zha et al., 1996) at the level of the mitochondria. We have shown that Bcl protein family members can be modulated by IGF-I (Singleton et al., 1996a). Therefore, we postulated that IGF-I would have an effect on events occurring at the mitochondrial level.

In the current study, we investigated the effects of hyperosmotic stress and IGF-I addition on the mitochondrial membrane potential, as a measure of mitochondrial function. Mannitol treatment results in a concentration dependent increase in the number of cells with depolarized mitochondria, as well as an increase in DNA fragmentation as measured by flow cytometry. IGF-I blocks mitochondrial depolarization and DNA fragmentation. These data suggest that IGF-I acts upstream of the mitochondria to prevent apoptosis in neuroblastoma cells. Bcl proteins, including Bcl-2 and Bcl- $\mathrm{X}_{\mathrm{L}}$, form pores in the outer mitochondrial membrane which regulate the mitochondrial permeability transition and the release of cytochrome $\mathrm{C}$ and apoptosis-inducing factor (AIF) into the cytosol (Marzo et al., 1998; Minn et al., 1997; Reed 1997; Schendel et al., 1997). The changes in mitochondrial membrane permeability alter membrane polarity. Cells undergoing apoptosis show a mitochondrial mem- 
brane depolarization which can be prevented by overexpression of Bcl- $\mathrm{X}_{\mathrm{L}}$ or Bcl-2, and this depolarization occurs prior to caspase activation (Susin et al., 1997; Vander Heiden et al., 1997). Therefore, IGF-I could prevent mitochondrial membrane depolarization in SH-SY5Y cells by affecting Bcl protein levels or activation, in turn preventing pore opening and release of AIF.

We next investigated the effect of IGF-I on activation of the more downstream caspases. The caspase family of proteins are cysteine proteases that are themselves cleaved to produce active enzymes (Villa et al., 1997). On activation, the caspases form a proteolytic cascade that ultimately causes apoptosis (Villa et al., 1997). Any interference in this cascade can affect the outcome of an apoptotic stimulus (Goldstein, 1997). We have previously shown that $24 \mathrm{~h}$ of hyperosmotic stress induces activation of two of the caspases, caspase-3 and caspase-7 (Singleton et al., 1996a). We chose to examine these two caspases further because they are downstream and essential for apoptosis to occur in many systems. When SH-SY5Y cells are exposed to hyperosmotic media, caspase-3 cleavage, and therefore activation, is seen as early as $9 \mathrm{~h}$. This cleavage is prevented by the addition of IGF-I. Total protein levels of caspase-3 remain unchanged however, indicating that regulation of caspase-3 by both hyperosmotic exposure and IGF-I is by regulating the enzyme activity, not by regulating protein transcription or translation.

Our data support recent studies suggesting that IGF-I exerts its protective effect upstream from the caspases. IGF-I binding to the IGF-IR can activate the phosphatidylinositol 3-kinase effector Akt/PKB which in turn phosphorylates the Bcl-2 family member Bad. Once phosphorylated, Bad can no longer bind Bcl- $\mathrm{X}_{\mathrm{L}}$ or Bcl-2 (Zha et al., 1996), allowing these proteins to exert their protective effect at the mitochondrial level, potentially by blocking the release of cytochrome $\mathrm{C}$, required for caspase activation (del Peso et al., 1997; Datta et al., 1997). Currently, we only know that IGF-IR activation prevents mitochondrial membrane depolarization and caspase- 3 cleavage, events that occur late in the above cascade. We are now examining the roles of Akt and Bad phosphorylation in neuroblastoma under conditions of hyperosmotic induced apoptosis and IGF-I rescue.

Several questions still remain that need further investigation. Does hyperosmotic shock affect apoptosis in other tumor cell types, and does serum rescue these other cell types as well? Does IGF-I prevent apoptosis solely through regulation of the Bcl proteins, or are other mechanisms involved? And finally, does IGF-I exert any protective effect through direct interference with the caspase cascade, or does IGF-I only effect proteins upstream from the caspases? These questions will be important to answer to understand how manipulating either IGF-I and/or other growth factors might prove beneficial in treating neuroblastoma.

\section{ACKNOWLEDGMENTS}

The authors thank Ms. Judy Boldt for expert secretarial assistance, Dr. James Russell for helpful discussions, and Mr. Michael Peacock for photographic preparation.

This work was supported by grants from NCI (Can- cer Biology Training Program Grant to C.V.G.), NIH (E.L.F.), American Diabetes Association (E.L.F.), and Juvenile Diabetes Foundation.

\section{LITERATURE CITED}

Biedler JL, Spengler BA, Tien-ding C, Ross RA. 1988. Transdifferentiation of human neuroblastoma cells results in coordinate loss of neuronal and malignant properties. Adv Neuroblastoma Res 2:265276.

Brodeur GM, Maris JM, Yamashiro DJ, Hogarty MD, White PS. 1997. Biology and genetics of human neuroblastomas. J Pediatr Hematol Oncol 19:93-101.

Bunone G, Mariotti A, Compagni A, Morandi E, Della Valle G. 1997. Induction of apoptosis by p75 neurotrophin receptor in human neuroblastoma cells. Oncogene 14:1463-1470.

Cameron NE, Cotter MA, Low PA. 1991. Nerve blood flow in early experimental diabetes in rats: relation to conduction deficits. Am J Physiol 216:E1-8.

Castleberry RP. 1997. Biology and treatment of neuroblastoma. Pediatr Clin North Am 44:919-936.

Cheng H-L Feldman EL. 1998. Bi-directional regulation of p38 kinase and c-Jun N-terminal protein kinase by insulin-like growth factor-I. J Biol Chem 273:14560-14565.

Chinnaiyan AM, Orth K, O'Rourke K, Duan H, Poirer GG, Dixit VM. 1996. Molecular ordering of the cell death pathway: Bcl-2 and Bcl-X $\mathrm{L}_{\mathrm{L}}$ function upstream of the CED-3-like apoptotic proteases. J Biol Chem 271:4573-4576.

Cianfarani S, Rossi P. 1997. Neuroblastoma and insulin-like growth factor system - New insights and clinical perspectives. Eur J Pediatr 156:256-261.

Ciccarone V, Spengler BA, Meyers MB, Biedler JL, Ross RA. 1989 Phenotypic diversification in human neuroblastoma cells: expression of distinct neural crest lineages. Cancer Res 49:219-225.

da Motta LA, Galli P, Piva F, Maggi R. 1997. Effects of epidermal growth factor on the $[3 \mathrm{H}]$-thymidine uptake in the SK-N-SH and SH-SY5Y human neuroblastoma cell lines. Arq Neuropsiquiatr 55: 444-451.

Datta SR, Dudek H, Tao X, Masters S, Fu H, Gotoh Y, Greenberg ME. 1997. Akt phosphorylation of BAD couples survival signals to the cell-intrinsic death machinery. Cell 91:231-241.

del Peso L, Gonzalez-Garcia M, Page C, Herrera R, Nunez G. 1997. Interleukin-3-induced phosphorylation of $\mathrm{BAD}$ through the protein kinase Akt. Science 278:687-689.

Deshmukh M Johnson EM, Jr. 1997. Programmed cell death in neurons: focus on the pathway of nerve growth factor deprivationinduced death of sympathetic neurons. Mol Pharmacol 51:897-906.

Ehrhard PB, Ganter U, Schmutz B, Bauer J, Otten U. 1993. Expression of low-affinity NGF receptor and trkB mRNA in human SHSY5Y neuroblastoma cells. FEBS Lett 330:287-292.

Falcione M, Milligan KD, Schwartz MC, Schor NF. 1993. Prevention of neocarzinostatin-induced cell death and morphologic change in SK-N-SH human neuroblastoma cells by continuous exposure to nerve growth factor. Biochem Pharmacol 46:731-738.

Funa K, Ahgren A. 1997. Characterization of platelet-derived growth factor (PDGF) action on a mouse neuroblastoma cell line, NB41, by introduction of an antisense PDGF beta-receptor RNA. Cell Growth Differ 8:861-869.

Gelbard HA, Boustany RM, Schor NF. 1997. Apoptosis in development and disease of the nervous system .2. Apoptosis in childhood neurologic disease. Pediatr Neurol 16:93-97.

Goldstein P. 1997. Controlling cell death. Science 275:1081-1082.

Hickman JA. 1992. Apoptosis induced by anticancer drugs. Cancer Metastasis Rev 11:121-129.

Jacobson MD, Weil M, Raff MC. 1997. Programmed cell death in animal development. Cell 88:347-354.

Janet T, Lüdecke G, Otten U, Unsicker K. 1995. Heterogeneity of human neuroblastoma cell lines in their proliferative responses to basic FGF, NGF, and EGF: Correlation with expression of growth factors and growth factor receptors. J Neurosci Res 40:707-715.

Janicke RU, Sprengart ML, Wati MR, Porter AG. 1998. Caspase-3 is required for DNA fragmentation and morphological changes associated with apoptosis. J Biol Chem 273:9357-9360.

Jensen LM, Zhang Y, Shooter EM. 1992. Steady-state polypeptide modulations associated with nerve growth factor (NGF)-induced terminal differentiation and NGF deprivation-induced apoptosis in human neuroblastoma cells. J Biol Chem 267:19325-19333.

Kerr JFR, Winterford CM, Harmon BV. 1994. Apoptosis. Its significance in cancer and cancer therapy. Cancer 73:2013-2026.

Kornblum HI, Hussain R, Wiesen J, Miettinen P, Zurcher SD, Chow 
K, Derynck R, Werb Z. 1998. Abnormal astrocyte development and neuronal death in mice lacking the epidermal growth factor receptor. J Neurosci Res 53:697-717.

Kuner P, Hertel C. 1998. NGF induces apoptosis in a human neuroblastoma cell line expressing the neurotrophin receptor p75NTR. J Neurosci Res 54:465-474.

Lavenius E, Gestblom C, Johansson I, Nanberg E, Pahlman S. 1995. Transfection of TRK-A into human neuroblastoma cells restores their ability to differentiate in response to nerve growth factor. Cell Growth Differ 6:727-736.

Lavenius E, Parrow V, Nånberg E, Påhlman S. 1994. Basic FGF and IGF-I promote differentiation of human SH-SY5Y neuroblastoma cells in culture. Growth Factors 10:29-39.

Leventhal PS, Randolph AE, Vesbit TE, Schenone A, Windebank AJ, Feldman EL. 1995. Insulin-like growth factor-II as a paracrine growth factor in human neuroblastoma cells. Exp Cell Res 221:179186.

Martin DM Feldman EL. 1993. Regulation of insulin-like growth factor-II expression and its role in autocrine growth of human neuroblastoma cells. J Cell Physiol 155:290-300.

Martin DM, Singleton JR, Meghani MA, Feldman EL. 1993. IGF receptor function and regulation in autocrine human neuroblastoma cell growth. Regul Pept 48:225-232.

Martin SJ, Green DR. 1995. Apoptosis and cancer: the failure of controls on cell death and cell survival. Crit Rev Oncol Hematol 18:137-153.

Marzo I, Brenner C, Zamzami N, Susin SA, Beutner G, Brdiczka D, Remy R, Xie ZH, Reed JC, Kroemer G. 1998. The permeability transition pore complex: a target for apoptosis regulation by caspases and bcl-2-related proteins. J Exp Med 187:1261-1271.

Matthews CC, Feldman EL. 1996. Insulin-like growth factor I rescues SH-SY5Y human neuroblastoma cells from hyperosmotic induced programmed cell death. J Cell Physiol 166:323-331.

Matthews CC, Odeh H, Feldman EL. 1997. Insulin-like growth factor-I is an osmoprotectant in human neuroblastoma cells. Neuroscience 79:525-534.

Minn AJ, Velez P, Schendel SL, Liang H, Muchmore SW, Fesik SW, Fill M, Thompson CB. 1997. Bcl- $x_{\mathrm{L}}$ forms an ion channel in synthetic lipid membranes. Nature 385:353-357.

Murai N, Ueba T, Takahashi JA, Yang HQ, Kikuchi H, Hiai H, Hatanaka M, Fukumoto M. 1996. Apoptosis of human glioma cells in vitro and in vivo induced by a neutralizing antibody against human basic fibroblast growth factor. J Neurosurg 85:1072-1077.

Nakagawara A, Brodeur GM. 1997. Role of neurotrophins and their receptors in human neuroblastomas: a primary culture study. Eur J Cancer 33:2050-2053.

Nakagawara A, Nakamura Y, Ikeda H, Hiwasa T, Kuida K, Su M, Zhao H, Cnaan A, Sakiyama S. 1997. High levels of expression and nuclear localization of interleukin- $B$ converting enzyme (ICE) and CPP32 in favorable human neuroblastoma. Cancer Res 57:45784584 .

Neuwelt EA, Howieson J, Frenkel EP, Specht HD, Weigel R, Buchan CG, Hill SA. 1986. Therapeutic efficacy of multiagent chemotherapy with drug delivery enhancement by blood-brain-barrier modification in glioblastoma. Neurosurgery 19:573-582.

Neuwelt EA, Rapoport SI. 1984. Modification of the blood-brain barrier in the chemotherapy of malignant brain tumors. Fed Proc $43: 214-219$.
O'Connor R. 1998. Survival factors and apoptosis. Adv Biochem Eng Biotechnol 62:137-166.

Pahlman S, Johansson I, Westermark B, Nister M. 1992. Plateletderived growth factor potentiates phorbol ester-induced neuronal differentiation of human neuroblastoma cells. Cell Growth Differ 3:783-790.

Pittman RN, Wang S, DiBenedetto AJ, Mills JC. 1993. A system for characterizing cellular and molecular events in programmed neuronal cell death. J Neurosci 13:3669-3680.

Poluha W, Poluha DK, Ross AH. 1995. TrkA neurogenic receptor regulates differentiation of neuroblastoma cells. Oncogene 10:185189.

Reed JC. 1997. Double identity for proteins of the Bcl-2 family. Nature 387:773-776.

Schendel SL, Xie Z, Montal MO, Matsuyama S, Montal M, Reed JC. 1997. Channel formation by antiapoptotic protein Bcl-2. Proc Natl Acad Sci U S A 94:5113-5118.

Schulte-Hermann R, Grasl-Kraupp B, Bursch W. 1994. Tumor development and apoptosis. Int Arch Allergy Immunol 105:363-367.

Singleton JR, Randolph AE, Feldman EL. 1996a. Insulin-like growth factor I receptor prevents apotosis and enhances neuroblastoma tumorigenesis. Cancer Res 56:4522-4529.

Singleton JR, Dixit VM, Feldman EL. 1996b. Type I insulin-like growth factor receptor activation regulates apoptotic proteins. J Biol Chem 271:31791-31794.

Soriano P. 1997. The PDGF $\alpha$ receptor is required for neural crest cell development and for normal patterning of the somites. Development 124:2691-2700

Susin SA, Zamzami N, Castedo M, Daugas E, Wang HG, Geley S, Fassy F, Reed JC, Kroemer G. 1997. The central executioner of apoptosis: multiple connections between protease activation and mitochondria in Fas/APO-1/CD95-and ceramide induced apoptosis. J Exp Med 186:25-37.

Taiji M, Taiji K, Deyerle KL, Bothwell M. 1992. Basic fibroblast growth factor enhances nerve growth factor receptor gene promoter activity in human neuroblastoma cell line CHP100. Mol Cell Biol 12:2193-2202

Vander Heiden MG, Chandel NS, Williamson EK, Schumacker PT, Thompson CB. 1997. Bcl-xl regulates the membrane potential and volume homeostasis of mitochondria. Cell 91:627-637.

Villa P, Kaufmann SH, Earnshaw WC. 1997. Caspases and caspase inhibitors. Trends Biochem Sci 22:388-393.

Vogelbaum MA, Tong JX, Rich KM. 1998. Developmental regulation of apoptosis in dorsal root ganglion neurons. J Neurosci 18:89288935.

Wieder R, Wang H, Shirke S, Wang Q, Menzel T, Feirt N, Jakubowski AA, Gabrilove JL. 1997. Low level expression of basic FGF upregulates Bcl-2 and delays apoptosis, but high intracellular levels are required to induce transformation in NIH 3T3 cells. Growth Factors $15: 41-60$.

Woo M, Hakem R, Soengas MS, Duncan GS, Shahinian A, Kagi D Hakem A, McCurrach M, Khoo W, Kaufman SA, Senaldi G, Howard T, Lowe SW, Mak TW. 1998. Essential contribution of caspase 3/CPP32 to apoptosis and its associated nuclear changes. Genes Dev 12:806-819.

Zha J, Harada H, Yang E, Jockel J, Korsmeyer SJ. 1996. Serine phosphorylation of death agonist $\mathrm{BAD}$ in response to survival factor results in binding to $14-3-3$ not BCL- $\mathrm{X}_{\mathrm{L}}$. Cell 87:619-628. 